DOI https://doi.org/10.18551/rjoas.2017-11.50

\title{
CONTRIBUTION OF GREEN FERTILIZER (CLOTARIA JUNCEA L.) ON EFFICIENCY OF ABSORPTION ARTIFICIALS FERTILIZER (NPK) ON SUNAN CANDLENUT GROWTH (REUTEALIS TRISPERMA (BLANCO) AIRY SHAW) IN DRY LAND WITH DRY CLIMATE
}

\author{
Santoso B. *, Cholid M., Stiana H. \\ Sweetener and Fiber Crops Research Institute, Indonesian Agency for Agricultural Research \\ and Development, Indonesia \\ *E-mail: b santoso111@yahoo.com
}

\begin{abstract}
Candlenut (Reutealis trisperma (Blanco) Airy Shaw) is a part of timber plant stand that has a width dense canopy. The ability to absorb $\mathrm{CO}^{2}$ is very high because of the large photosynthetic rate, therefore it is classified as a plant that is environmentally friendly. Furthermore Candlenut can be used as conservation of degraded or marginal land. In dry areas, Sunan candlenut can grow well, because the carbon's system tracks type C4 is more efficient than the trajectory Carbon C3 in water use. On dry land is generally the main problem, in addition to the water is the availability of low organic matter, resulting in the plants cultivated by farmers is less encouraging production. Candlenut at that time is always blooming and deciduous, contains quite large biomass and can be used to add organic substantial. The research was conducted during the growing season in 2016 at the experimental station Asembagus Situbondo, Crops Research Institute for sweetener and Fiber. The research location at coordinates $7^{\circ} 45^{\prime} 18,39$ "LS (south latitude) and $114^{\circ}$ 15'27,63" longitude (east longitude), regosol soil type with D3 climate type. The planting material used KS 1 candlenut varieties coming from the middle of the dial. Rootstock (rootstock) used is 1 Sunan candlenut varieties derived from the seeds. Average planting materials for the upper stem (entrees) were taken from candlenut varieties of seeds 1 and 2 but which has ripe fruit. Seeds planted in polybag after 5-months-old moved into the field. Spacing $5 \mathrm{~m} \times 5 \mathrm{~m}$ with a planting hole, the hole size is $50 \mathrm{~cm} \times 50 \mathrm{~cm}$ to $50 \mathrm{~cm}$ into the plant. In the field polybag seedlings planted during the rainy season. $5 \mathrm{~kg}$ fertilizer to each planting hole. Clotaria Juncea seeds planted from seed among candlenut, spacing $20 \mathrm{~cm} x$ $20 \mathrm{~cm}$, after 3-months-old Clotalaria Juncea it will be cut. $5 \mathrm{~kg}$ to each candlenut tree Clotaria Juncea, by way of embedded around the plant. The treatment design used Randomized Block Design (RBD) factorial which repeated 3 times. First Factor green fertilizer (Clotaria Juncea L.), which consists of two doses: 1). C0 without being given Clotaria Juncea L.; 2). $C 1$ given Clotaria Juncea $L$. $5 \mathrm{~kg} /$ candlenut tree. The second factor with a dose of inorganic fertilizer; 1). P0 without fertilizer; 2). P1 $70 \mathrm{~g}$ urea $+25 \mathrm{gr} \mathrm{SP}-36+60 \mathrm{gr} \mathrm{KCl} ; 3)$. P2 $140 \mathrm{~g}$ of urea + $50 \mathrm{~g} \mathrm{SP}-36+120 \mathrm{gr} \mathrm{KCl}$; and 4). P3 $280 \mathrm{gr} \mathrm{Urea}+100 \mathrm{gr} \mathrm{SP}-36+240 \mathrm{gr} \mathrm{KCl}$. In total there are 24 treatments research plot size: $40 \mathrm{~m} \times 20 \mathrm{~m}$. The observed parameters (plant height, stem diameter, number of branches, and the width of the canopy. The results of the research, the provision of green fertilizer (Clotaria Juncea L.) with $5 \mathrm{~kg}$ dose and a combination of inorganic Urea fertilizer $140 \mathrm{gr}+50 \mathrm{gr} \mathrm{SP}-36+120 \mathrm{gr} \mathrm{KCl} /$ trees provide optimum growth for Candlenut (plant height, stem diameter, canopy width and the number of branches). Giving Clotaria Juncea can increase the land and the plants resonant capacity and reduce the use of inorganic fertilizer. The research objective of this green fertilizer is organic material in the soil, therefore the location of research activities has increased and nutrients required candlenut is provided for the growth and increase the land resonant capacity.
\end{abstract}

\section{KEY WORDS}

Candlenut, Clotaria Juncea, green fertilizer.

Before the green revolution on 1850, the farmers used organic substantial fertilizer. However, after the discoveries of inorganic fertilizer, there is basic revolution in agricultural 
sector. The farmers are dealing with natural resources which are not a concept of environmentally sustainability. But, they only want high production without concerning agroecological friendliness. Local wisdom should be maintained in order to achieve renewable and sustainable natural resources. Organic substantial as a solid base for maintaining soil strength, both in terms of physically, chemical, and soil biology. Soil health is habitually categorized as soil quality (Doran and Zeiss, 2000). The result of Abbott and Murphy (2003) research indicates that the optimal soil strength is highly dependent on the equivalence between physically, chemical, and biological fertility. According to Djajadi (2015) examined that the decreasing of soil organic substantial content negatively affect the physical, chemical and soil's biological properties. The decreasing of soil health instigated production and the environmental damage caused by global warming (Rees et al., 2005; Schulze and Freibauer, 2005). The further explanation examined that this was due to excessive inorganic fertilizers result's underground which pollute the ground water. The condition of the research field has an organic substantial content of only about $0.25 \%$ which is categorized as very low. Therefore, the addition of organic substantial from green fertilizer (Clotaria Juncea L.) is necessary, thus the nutrients in soil is adequately available for sunan candlenut's growth. The provision of organic substantial in addition to its role as a source of energy and soil microbial food can also increase microbial activity. According to Andiningsih (2005), the ideal organic substantial for plant growth is about 3-5\%.

Sunan candlenut (Reutealis trisperma (Blanco) Airy Shaw is an environmentally friendly biofuel producer because it has low free greasy acids, thus when being used for diesel-fueled diesel engines it is virtually non-acidic and free of heavy metals. According to Pranowo et al., 2015, stated that biofuel plants such as jarak pagar (Jatropha curcas L.), Kepuh (Sterculia foetida) and Bintaro (Cerbera manghas), Yamplung (Calophyllum inophyllum L.), Kosambi (Schlechera oleosa) and Pongamia (Pongamia pinnata) have only about $10-30 \%$ oil content. Meanwhile, sunan candlenut oil can reach about 50-54\%. Besides, candlenut oil cannot be used for food necessities; therefore it is safe from the competition of the source of food supply. Another advantage of candlenut has a wide and lush canopy shape and a large photosynthesis process; therefore it is not surprising that it can absorb high $\mathrm{CO}^{2}$. Each sunan tree that is more than 25 years old can absorb $\mathrm{CO}^{2}$ of 1.60 tons / tree (Herman, 2011). At the blossoming time in the dry season, sunan candlenut is experiencing leaf miscarriage; therefore it can add litter to the soil and can increase soil fertility.

Oil necessity as fuel continues to increase in line with the development pace. While the oil refineries exploration is undergoing difficulties, there is nothing new, just continuing on the old wells. Formerly, Indonesia which initially became an oil exporter turned into an oil importer. World concerns about the fuel oil availability begin to appear. It is estimated that 75 years from now the source of fossil fuel reserves will no longer available. Therefore, alternative and renewable fuels are required. By 2050 it is expected that the new and renewable energy role will increase by at least $31 \%$ while the role of petroleum is less than $20 \%$ (Perpres 2014). The approach through vegetable oil as new and renewable energy is the most appropriate step, because the oil source comes from a plant that is certainly renewable and sustainable.

The objective of this green fertilizer addition research is to keep the index of organic substantial on the soil in the research location activities and the nutrients required by sunan candlenut are more available for growth and increase the land resonant capacity.

\section{MATERIALS AND METHOD OF RESEARCH}

The research was conducted at the Asem Bagus Experimental Garden of Indonesian Sweetener and Fiber Crops Research Institute. The research location is on coordinates $7^{\circ}$ 45'18,39" LS (South Latitude) and 114 15'27,63" BT (East Longitude), starting on the beginning of 2016. Type of regosol soil with D3 climate type is in Situbondo regency. Sunan candlenut KS 1 variety is used as planting materials which comes from central relations. The variety of sunan candlenut 1 is used as rootstock which originates from seeds. Meanwhile, the planting material for the top stem (entrees) is taken from the varieties of candlenut herbs 
1 and 2 of the seeds which only have been fruitful. The seeds are grown in polybags after 5 months-old moved to the field. $5 \mathrm{~m} \times 5 \mathrm{~m}$ spacing with one planting hole. The hole size is 40 $\mathrm{cm} \times 50 \mathrm{~cm}$ with planting depth about $50 \mathrm{~cm}$. Seedlings in polybags planted on the field during the rainy season. Each planting hole is given fertilizer as much as $5 \mathrm{~kg}$. Clotaria Juncea is grown with seeds between the seeds of sunan candlenut. $20 \mathrm{~cm} \times 20 \mathrm{~cm}$ spacing. After Clotaria Juncea turns into 3 months old, it will be cut. Each candlenut tree is given $5 \mathrm{~kg}$ Clotaria Juncea, embedded around the plant.

Randomized Factorial Randomized Design (RAK) is used as the treatment design which was factorial within 3 times repeating. The first factor of green fertilizer (Clotaria Juncea L.) consisting of 2 doses: 1). C0 without being given Clotaria Juncea L.; 2). C1 was given Clotaria Juncea $L$. as much as $5 \mathrm{~kg} /$ sunan candlenut tree. The second factor is inorganic fertilizer with dose; 1). P0 without fertilizer; 2). P1 70 gr Urea $+25 \mathrm{gr} \mathrm{SP}-36+60 \mathrm{gr}$ $\mathrm{KCl}$; 3). P2 $140 \mathrm{gr} U r e a+50 \mathrm{gr} \mathrm{SP}-36+120 \mathrm{gr} \mathrm{KCl}$;). P3 $280 \mathrm{gr}$ Urea + $100 \mathrm{gr} \mathrm{SP}-36+$ $240 \mathrm{gr} \mathrm{KCl}$. Total treatment was 24 . The size of study plot: $5 \mathrm{~m} \times 5 \mathrm{~m}$. The application of artificial fertilizer is being buried into the soil. The observed parameters included diameter, number of branches, number of leaves, and width of the canopy. The before and after soil analysis was done on experimental soil. The results of soil analysis before the research are presented in Table 1. The tools used were sit-scale, term slot, and prism. Each plot is given a number according to the treatment being attempted. The treatment placement in plots is randomized to each replication.

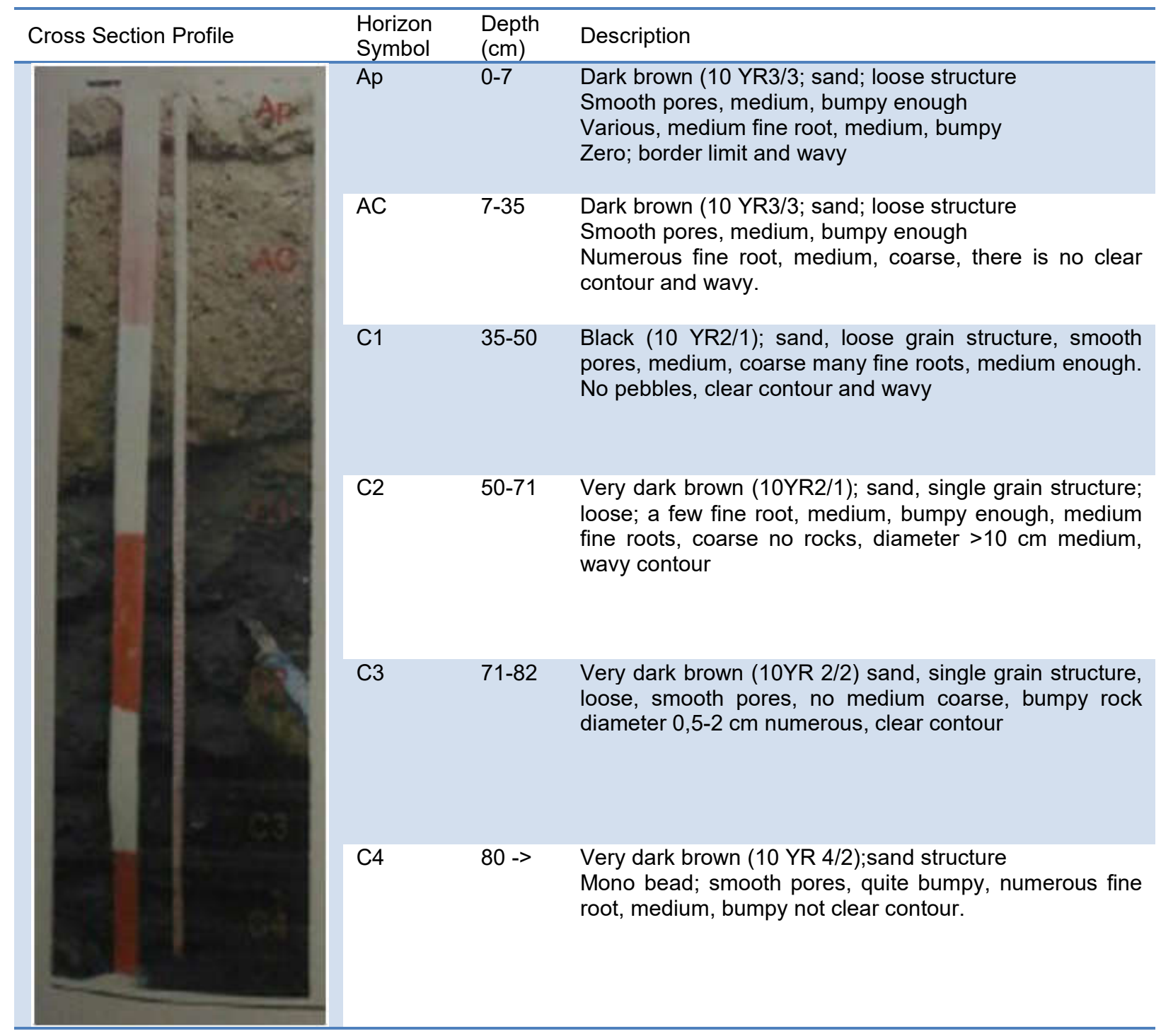

Source: Budi Hariyono (2016). 
Description of the soil profile at the location of the research activity:

- Seri: Asembagus Situbondo

- Observation method: Minipit

- Evelation: $46 \mathrm{dpl}$

- Physiography: Lower land

- Angles: 3\%

- Position: Valley

- Mainstay base: Medium

- Drainage: Rapid

- Flood: Zero

- Erosion Damage: Light

- Land-use: Mixed garden

- Effective depth: $>120 \mathrm{n} \mathrm{cm}$

- Vegetation: Jatropha Curcas, cotton plant, corn, cane, Ricinus Communis, sesame

- Ingredients: Volcanic

- Description by: Kustani Wahyu Utami

\section{Classification}

- Soil moisture regime: Ustik

- Soil temperature regim: Isotherm

- Epipedon: Okrik

- Endopedon: -

- Ordo: Entisol

- Sub ordo: Ustipsemments

- Sub group: Typical Ustipsamments (soil Survey Staff, 2010)

Table 1 - The analysis of Asembagus ground attempt result before research

\begin{tabular}{|c|c|c|c|}
\hline No & Analysis Type & Score & Category \\
\hline 1. & $\mathrm{pH} 1: 1 \mathrm{H} 2 \mathrm{O}$ & 6,50 & A little sour \\
\hline 2. & $\mathrm{pH} \mathrm{1:1} \mathrm{HCl}$ & 6,05 & \\
\hline 3. & C-Organic (\%) & 0,25 & Very Low \\
\hline 4. & $\mathrm{~N}$-total $(\%)$ & 0,05 & Very Low \\
\hline 5. & $\mathrm{C} / \mathrm{N}$ & 4,50 & Very Low \\
\hline \multirow[t]{2}{*}{6.} & P. Bray $2(\mathrm{mg} / \mathrm{kg})$ & 30,46 & High \\
\hline & $\mathrm{NH}_{4} \mathrm{OAc} 1 \mathrm{~N} \mathrm{pH} 7(\mathrm{me} / 100 \mathrm{~g})$ & & \\
\hline 7. & $\mathrm{~K}$ & 1,32 & Very Low \\
\hline 8. & $\mathrm{Na}$ & 2,22 & Very High \\
\hline 9. & $\mathrm{Ca}$ & 4,77 & Low \\
\hline 10. & $\mathrm{Mg}$ & 1,59 & Average \\
\hline 11. & KTK & 13,18 & Low \\
\hline 12. & Number of bases & 9,90 & \\
\hline 13. & $\mathrm{~KB}(\%)$ & 76,00 & Very High \\
\hline 14. & Sand & 91,50 & \\
\hline 15. & Dusk & 7,00 & \\
\hline 16. & Clay & 1,50 & \\
\hline 17. & Texture & Sand & \\
\hline
\end{tabular}

Soil analyzed at Soil Laboratory of Faculty of Agriculture University of Brawijaya.

\section{RESULTS AND DISCUSSION}

From the variance analysis indicates that the treatment of green and inorganic fertilizer, there is an interaction that occurs in sunan candlenut high growth. The full results are presented in Table 2. 
Table 2 - Interaction between green and inorganic fertilizer application to plant height

\begin{tabular}{|c|c|c|c|c|c|c|}
\hline \multirow{2}{*}{ Treatment } & \multicolumn{7}{|c|}{ Plant Height (cm) } \\
\cline { 2 - 6 } & May & June & July & August & September & October \\
\hline CoPo & $36,67 \mathrm{~b}$ & $62,13 \mathrm{~d}$ & $89,50 \mathrm{~b}$ & $111,31 \mathrm{e}$ & $118,38 \mathrm{e}$ & $123,32 \mathrm{e}$ \\
CoP1 & $44,04 \mathrm{ab}$ & $69,38 \mathrm{~cd}$ & $91,17 \mathrm{ab}$ & $114,13 \mathrm{~d}$ & $124,77 \mathrm{c}$ & $127,75 \mathrm{~d}$ \\
CoP2 & $47,71 \mathrm{ab}$ & $74,46 \mathrm{cbd}$ & $101,79 \mathrm{ab}$ & $117,25 \mathrm{c}$ & $122,36 \mathrm{~d}$ & $127,06 \mathrm{~d}$ \\
CoP3 & $44,29 \mathrm{ab}$ & $63,50 \mathrm{~d}$ & $98,04 \mathrm{ab}$ & $119,78 \mathrm{c}$ & $121,94 \mathrm{~d}$ & $127,97 \mathrm{~d}$ \\
C1P0 & $50,21 \mathrm{ab}$ & $79,67 \mathrm{abc}$ & $108,00 \mathrm{ab}$ & $122,79 \mathrm{~b}$ & $127,93 \mathrm{~b}$ & $134,80 \mathrm{c}$ \\
C1P1 & $51,75 \mathrm{a}$ & $86,58 \mathrm{ab}$ & $110,25 \mathrm{ab}$ & $124,60 \mathrm{~b}$ & $127,99 \mathrm{~b}$ & $135,83 \mathrm{~b}$ \\
C1P2 & $56,08 \mathrm{a}$ & $90,71 \mathrm{a}$ & $117,79 \mathrm{a}$ & $129,99 \mathrm{a}$ & $132,38 \mathrm{a}$ & $137,71 \mathrm{a}$ \\
C1P3 & $45,83 \mathrm{ab}$ & $85,42 \mathrm{ab}$ & $111,25 \mathrm{ab}$ & $123,99 \mathrm{~b}$ & $126,89 \mathrm{~b}$ & $133,97 \mathrm{c}$ \\
\hline
\end{tabular}

The accompanied value of the same letter in the same column is not significantly different in Duncan $5 \%$ test.

Table 2 shows that C1P2 treatment provides optimal plant height growth. This is suspected that the soil used for experiments affecting Juncea by $5 \mathrm{~kg} /$ tree increased the high growth of the sunan candlenut plant.

Organic fertilizer has a significant effect on the increase of soil and plant productivity. According to Hartatik and Setyorini (2012) stated that the role of organic fertilizer to the soil physical properties are a). Improve soil structure because organic substantial can bind soil particles into a solid aggregate; $b$ ). Improve the soil pore size distribution, thus the water holding capacity of the soil becomes better and the air movement (aeration) in the soil is smooth and c).reduce (buffer) soil temperature fluctuations. Furthermore, it was suggested that the role of organic fertilizer on soil biology is as an energy source and food for micro and meso soil fauna. In the end the availability of sufficient organic material in the soil activity of organisms to be developed with an optimal that is not directly related to the availability of nutrients, nutrient cycles and the micro pore and macro formation soil for the better.

The variance analysis indicates that the treatment of green and inorganic fertilizer interaction of stem diameter growth. The complete results are listed in Table 3.

Table 3 - Interaction between the application of green and inorganic fertilizer to stem diameter

\begin{tabular}{|c|c|c|c|c|c|c|}
\hline \multirow{2}{*}{ Treatment } & \multicolumn{5}{|c|}{ Stem Diameter ( mm) } \\
\cline { 2 - 7 } & May & June & July & August & September & October \\
\hline CoPo & $16,87 \mathrm{~b}$ & $22,37 \mathrm{bc}$ & $28,01 \mathrm{~d}$ & $35,83 \mathrm{~g}$ & $38,54 \mathrm{e}$ & $40,95 \mathrm{e}$ \\
CoP1 & $18,29 \mathrm{ab}$ & $23,25 \mathrm{abc}$ & $28,88 \mathrm{c}$ & $36,44 \mathrm{f}$ & $38,50 \mathrm{e}$ & $41,41 \mathrm{de}$ \\
CoP2 & $18,42 \mathrm{ab}$ & $23,51 \mathrm{abc}$ & $29,22 \mathrm{c}$ & $37,00 \mathrm{ef}$ & $38,75 \mathrm{e}$ & $41,64 \mathrm{~cd}$ \\
CoP3 & $17.90 \mathrm{ab}$ & $21,30 \mathrm{c}$ & $29,44 \mathrm{c}$ & $37,33 \mathrm{de}$ & $40,07 \mathrm{~d}$ & $41,37 \mathrm{de}$ \\
C1P0 & $20,06 \mathrm{ab}$ & $25,05 \mathrm{abc}$ & $30,79 \mathrm{~b}$ & $37,73 \mathrm{~cd}$ & $40,41 \mathrm{~cd}$ & $42,37 \mathrm{c}$ \\
C1P1 & $20,48 \mathrm{ab}$ & $25,44 \mathrm{ab}$ & $31,01 \mathrm{~b}$ & $38,11 \mathrm{bc}$ & $41,00 \mathrm{bc}$ & $43,17 \mathrm{~b}$ \\
C1P2 & $20,73 \mathrm{a}$ & $26,56 \mathrm{a}$ & $31,78 \mathrm{a}$ & $38,86 \mathrm{a}$ & $41,76 \mathrm{a}$ & $44,44 \mathrm{a}$ \\
C1P3 & $19,91 \mathrm{ab}$ & $25,86 \mathrm{ab}$ & $31,06 \mathrm{ab}$ & $38,50 \mathrm{ab}$ & $41,29 \mathrm{ab}$ & $42,72 \mathrm{bc}$ \\
\hline
\end{tabular}

The accompanied value of the same letter in the same column is not significantly different in Duncan $5 \%$ test.

The C1P2 treatment provides the best stem diameter growth. The circular growth is one of the signs which can be used as an indication of the sunan candlenut plant growth rate. The faster the growth rate of sunan candlenut planting should be supported by the availability of sufficient organic material for the plant. According to Hamid (1991), the necessity for C-Organik in candlenut is based on the land suitability of $>0.4 \%$. The speed of Clotaria Juncea green fertilizer in its activity and its function is strongly influenced by abiotic factors such as $\mathrm{pH}$, temperature and local environment and substrate. In such conditions there is a tight competition between similar microbes or various other microbes. The process of green fertilizer becomes available for the plant, not separated from the microbial work which eats the cellulose and lignin; therefore quickly produce nutrients which can substitute the necessity of inorganic fertilizer for the plant. According Turmuktini et, al., (2012) stated that a method to minimalize inorganic fertilizer usage is by using green fertilizer or organic fertilizer.

The results of the variance analysis indicate that the treatment attempted interaction between Clotaria Juncea and inorganic fertilizer to canopy width (Table 4). 
Table 4 - Interaction between green fertilizer and inorganic fertilizer application to canopy width

\begin{tabular}{|c|c|c|c|c|c|c|}
\hline \multirow{2}{*}{ Treatment } & \multicolumn{7}{|c|}{ Canopy Width (cm) } \\
\cline { 2 - 7 } & May & June & July & August & September & October \\
\hline CoPo & $68,79 \mathrm{e}$ & $86,42 \mathrm{ab}$ & $91,14 \mathrm{c}$ & $95,38 \mathrm{ab}$ & $95,91 \mathrm{~b}$ & $101,52 \mathrm{~d}$ \\
CoP1 & $73,84 \mathrm{c}$ & $86,92 \mathrm{ab}$ & $93,88 \mathrm{~b}$ & $94,92 \mathrm{ab}$ & $95,81 \mathrm{~b}$ & $103,24 \mathrm{~d}$ \\
CoP2 & $75,93 \mathrm{~b}$ & $90,92 \mathrm{ab}$ & $91,83 \mathrm{c}$ & $95,81 \mathrm{ab}$ & $95,22 \mathrm{~b}$ & $112,44 \mathrm{c}$ \\
CoP3 & $70,20 \mathrm{~d}$ & $85,50 \mathrm{~b}$ & $86,22 \mathrm{~d}$ & $91,08 \mathrm{~b}$ & $93,39 \mathrm{~b}$ & $115,85 \mathrm{~b}$ \\
C1P0 & $71,28 \mathrm{~d}$ & $94,50 \mathrm{ab}$ & $93,26 \mathrm{~b}$ & $98,58 \mathrm{ab}$ & $99,61 \mathrm{ab}$ & $116,00 \mathrm{~b}$ \\
C1P1 & $76,30 \mathrm{~b}$ & $96,63 \mathrm{a}$ & $96,47 \mathrm{ab}$ & $95,75 \mathrm{ab}$ & $96,22 \mathrm{~b}$ & $102,32 \mathrm{~d}$ \\
C1P2 & $78,07 \mathrm{a}$ & $96,29 \mathrm{a}$ & $97,11 \mathrm{a}$ & $103,13 \mathrm{a}$ & $106,29 \mathrm{a}$ & $125,10 \mathrm{a}$ \\
C1P3 & $71,30 \mathrm{~d}$ & $93,00 \mathrm{ab}$ & $94,37 \mathrm{~b}$ & $100,46 \mathrm{ab}$ & $101,39 \mathrm{ab}$ & $113,21 \mathrm{c}$ \\
\hline
\end{tabular}

The accompanied value of the same letter in the same column is not significantly different in Duncan $5 \%$ test.

Table 4 shows that giving Clotaria Juncea by $5 \mathrm{~kg} /$ sunan candlenut tree with inorganic fertilizer as much as $140 \mathrm{gr}$ Urea $+50 \mathrm{gr} \mathrm{SP}-36+120 \mathrm{gr} \mathrm{KCl} /$ tree can give the best canopy width. The canopy width is an indicator that the rooting arrangement is identical to the width of the canopy. If the canopy width is leafy then the roots arrangement is also wide, therefore the root penetration in search of nutrients in the ground is deeper.

From the ground propyl, it is seen that with Horizon AC symbol, depth 7-35 cm with dark brown color description (10 YR3 / 3) of loose structure sand, quite soft pore, adequate, quite rough, many smooth roots, adequate, clear, and bumpy boundaries. This indicates that the soil condition is dominated by sand, therefore very responsive when it is given green fertilizer to plant growth.

The parameters of branches number according to plant height, stem diameter and canopy width occurred interaction between Clotaria Juncea and inorganic fertilizer (Table 5).

Table 5 - Interaction between the application of green fertilizer and inorganic fertilizer to the branches number

\begin{tabular}{|c|c|c|c|c|c|c|}
\hline \multirow{2}{*}{ Treatment } & \multicolumn{7}{|c|}{ The Number of Branches } \\
\cline { 2 - 7 } & May & June & July & August & September & October \\
\hline CoPo & 0,00 & $0,00 \mathrm{~b}$ & $0,81 \mathrm{~b}$ & $2,49 \mathrm{~b}$ & $2,61 \mathrm{~d}$ & $2,86 \mathrm{~d}$ \\
CoP1 & 0,67 & $0,06 \mathrm{~b}$ & $1,31 \mathrm{ab}$ & $2,35 \mathrm{e}$ & $2,81 \mathrm{c}$ & $2,95 \mathrm{~d}$ \\
CoP2 & 0,00 & $0,00 \mathrm{~b}$ & $1,29 \mathrm{ab}$ & $2,69 \mathrm{c}$ & $2,81 \mathrm{c}$ & $2,932 \mathrm{~d}$ \\
CoP3 & 0,02 & $0,10 \mathrm{ab}$ & $1,17 \mathrm{ab}$ & $2,84 \mathrm{~b}$ & $3,08 \mathrm{~b}$ & $3,10 \mathrm{c}$ \\
C1P0 & 0,00 & $0,08 \mathrm{~b}$ & $1,23 \mathrm{ab}$ & $2,85 \mathrm{~b}$ & $3,05 \mathrm{~b}$ & $3,27 \mathrm{~b}$ \\
C1P1 & 0,00 & $0,00 \mathrm{~b}$ & $1,67 \mathrm{ab}$ & $2,94 \mathrm{~b}$ & $3,17 \mathrm{ab}$ & $3,29 \mathrm{~b}$ \\
C1P2 & 0,00 & $0,33 \mathrm{a}$ & $2,13 \mathrm{a}$ & $3,08 \mathrm{a}$ & $3,27 \mathrm{a}$ & $3,48 \mathrm{a}$ \\
C1P3 & 0,04 & $0,05 \mathrm{~b}$ & $1,73 \mathrm{ab}$ & $3,21 \mathrm{a}$ & $3,18 \mathrm{ab}$ & $3.27 \mathrm{~b}$ \\
\hline
\end{tabular}

The accompanied value of the same letter in the same column is not significantly different in the test.

Sunan candlenut has a rather unique number of branches, each of the first buds will appear 3 branches, therefore during the growth, it forms like a branching umbrella, these branches as the place for fruits. The C1P2 treatment consistently gives the appearance of the best number of branches.

Based on the condition of soil research in the dry season, water shortage happened. To keep the plants from weakness it is necessary to provide water from the well water drilling irrigation. Besides, the provision of water can help the plants in absorbing nutrients in the soil.

\section{CONCLUSION}

From this research, it can be concluded that the application of green fertilizer (Clotaria juncea L.) with $5 \mathrm{~kg}$ doses gives optimum growth for the sunan candlenut (plant height, stem diameter, leaf width and number of branches) with inorganic fertilizer combination of $140 \mathrm{gr}$ Urea $+50 \mathrm{gr} \mathrm{SP}-36+120 \mathrm{gr} \mathrm{KCl} /$ tree. Clotaria Juncea addition can increase the land resonant capacity and plants and can reduce the use of inorganic fertilizer. 


\section{REFERENCES}

1. Adiningsih, J.S. 2005. Peranan bahan organic tanah dalam meningkatkan kualitas dan produktivitas lahan Pertanian Dalam Materi Workshop dan Kongkres Nasional II Maporina. Sekretariat Mapoein, Jakarta.

2. Abbott, L. and D.V. Murphy. 2003. What is soil biological fertility ? in: Abbot, L.K., Murphy, D.V. (Eds). A key to Sustainable Land use Agriculture.p 1-15. Kluwer Academic Publishers. The Nedtherlands.

3. Doran, J.W. and Zeiss, M.R. 2000. Soil health and sustainability managing the biotic compone, nt of soil quality. Applied Soil Ecology. 15:3-11.

4. Djajadi .2015. Bahan Organik Peranannya dalam Budidaya Tebu Berkelanjutan. Journal Perspektif Review Penelitian Tanaman Industri Vol. 14 No. 1: 14-21.

5. Hariyono, B. 2016. Pemanfaatan Biochar Untuk Memperbaiki Kualitas Tanah Berstekstur Pasir dan Pengaruhnya pada Tebu (Saccharum officinarum L.). Desertasi Program Doktor Ilmu pertanian Bidang Studi Managemen Sumberdaya Lahan dan Lingkungan. Fakultas

6. Pertanian Universitas Brawijaya Malang Hal 1-190.

7. Hartatik, W. dan D. Setyorini. 2012. Pemanfaatan pupuk organic untuk meningkatkan kesuburan tanah dan kualitas tanaman. Prosiding Seminar Nasional Teknologi Pemupukan dan Pemulihan Lahan Terdegradasi p: 571-582.

8. Herman, M dan D. Pranowo. 2011. Budidaya candlenut sunan. Dalam Candlenut Sunan Sebagai Tanaman Konservasi dan Sumber Energi Terbarukan. Balittri. Puslitbang Perkebunan.p: 15-21.

9. Perpres (Peraturan Presiden Republik Indonesia) No 79 tahun 2014. Tentang kebijakan Energi Nasional.

10. Pranowo, D., M. Herman dan Syafaruddin. 2015. Potensi pengembangan candlenut sunan (Reutealis trisperma (Blanco) Airy Shaw) di lahan terdegradasi. Journal Perspektif Review Penelitian Tanaman Industri.Vol. 14 No.2. Hal 73-150.

11. Rees, RM., I.J. Bingham, J.A. Baddeley,C.A. Watson.2005. The role of plants and land management in sequestering soil carbon in temperate arabie and grassland ecosystems. Geoderma. 128: 130-154.

12. Schulze, E.D. and A. Freibauer. 2005. Environmental sciene-Catbon unlocke from soils. Nature.437 (7056):219-234.

13. Turmuktini, T., B. Natalie, Hersanti, Y. Yuwariah, B. Joy dan T. Simarmata. 2012. Kontribusi pupuk organic (kompos jerami +Pupuk Bio) untuk meningkatkan efisiensi pupuk anorganik ( $N, P, K)$ pertumbuhan dan hasil padi varietas ciherang dengan teknologi Ipat-BO. Prosiding Seminar Nasional Teknologi Pemupukan dan Pemulihan Lahan Terdegradasi p: 591-600. 